\title{
Africa's Development Trajectory: Lessons from China
}

\author{
JOHN OLUSHOLA MAGBADELO
}

Center for African and Asian Studies, Nigeria

ORCID: 0000-0001-8672-7208

\section{Made in Africa: Learning to Compete in Industry}

By Carol Newman, John Page, John Rand, Abebe Shimeles,

Mans Soderbon and Finn Tarp

Washington DC, Brookings Institution Press, 2016, xv + 268 pages, \$35 (paperback),

ISBN: 9780815728153

\section{Fifty Inventions that shaped the Modern Economy}

By Tim Harford

New York, Riverhead Books, 2017, iv+ 321 pages, $£ 8.16$ (hardcover), ISBN: 9780735216136

\section{Unlikely Partners: Chinese Reformers, Western Economists, and the making of Global China}

By Julian Gewirtz

Harvard University Press, 2017, iii + 389 pages, \$36 (hardcover), ISBN 9780674971134 
A frica has been experiencing an appreciable measure of economic growth since 1995. This palpable improvement in the African condition has meant that the Afro-pessimism of the previous decade had to be jettisoned for the more positive narrative captioned as Africa rising. Made in Africa by Carol Newman, et al. is the outcome of a research program on Learning to Compete (L2C) sponsored by the African Development Bank, the Brookings Institution, and the United Nations University World Institute for Development Economics Research (UNUWIDER) with the objective of identifying why there is so little industry in Africa despite the impressive record of economic growth being posted by the continent. This research, according to the authors, was undertaken to provide an explanation for why Africa's economic growth is not backed up with a requisite economic structure that could sustain the continent's development. The book focuses essentially on how Africa can industrialize and how its firms can compete in global markets of industrial goods. The authors' interest in embarking on the research and producing its findings in this compendium is to set a new agenda for industrial development in Africa. Using case studies approach, the authors chronicle the industrialization efforts and outcomes in Ethiopia, Ghana, Kenya, Mozambique, Nigeria, Senegal, Tanzania, Uganda, Tunisia, and two East Asia's newest industrializers -Cambodia and Vietnam- with a view to unearthing the problems militating against industrialization in Africa.
Made in Africa is about firms and what it would take for Africa to become a global industrial hub that would enable the continent to properly anchor its economic growth which has over time posted an impressive record of performance. The book has four broad parts. The first part stresses the importance of industry to Africa's economic development agenda. The second part, which consists of chapters 2 and 3, presents the historical quest for industrial development in Africa while assessing the industrial efforts and outcomes in all the eleven countries studied by the authors. The third part, which consists of chapters 4,5 and 6 , discusses the factors that could spur industrialization in Africa including firm productivity, exports, competition, firm capabilities, and industrial clusters. The last part, which consists of chapters 7,8 , and 9 , is an attempt by the authors to highlight policies and strategies that would stimulate industrialization in Africa: closing infrastructure and skills gaps, reforming regulations and institutions, pushing exports, policy and institutional reforms, improving trade logistics, strengthening regional infrastructure and institutions, and attracting Foreign Direct Investment (FDI). However, the authors are quick to point out that the outlined industrial strategy "would not succeed if it is implemented in a piecemeal or haphazard way." (pp. 180-181). They opine that the strategy 'calls for a level of coordination across government and a degree of engagement with private sector that is far more demanding than that anticipated by the investment 
climate reform agenda' (p. 181). Put differently, the authors have provided an anecdotal view of Africa's weak industrial base on the strength of the studies they conducted on nine African countries that were randomly chosen as representative samples of the continent. The argument they put forward is that Africa is not industrially developed because it lacks all the indices of industrial development. It is not helpful to list all the prevalent structures of industrial growth in other industrializing countries and present them as the requirements, conditions, or characteristic features of industrialization as the authors have done. True, most African countries lack what industrialized economies have in abundance. The near absence of industrial growth in Africa cannot be blamed on the absence of industrial policies but on the nonimplementation of extant policies on industrialization in most African countries.

The political economy of postcolonial Africa, with which the authors do not reckon, could in fact provide insight into the causation of the seeming entrenchment of poverty-inducing and weak economic structures in several African countries. Successive governments in postcolonial African countries appear incapacitated and therefore disinterested in changing the inherited structures of economic relations between their countries and the rest of the world. The public services of these countries function in such a way as to perpetuate the dependency of the continent on the rest of the world. Even when supposedly good industrial policies are imported or adopted by these African countries, the bureaucrats in their public services who ought to insist on their implementation do not feel obligated to do so. These bureaucratic elite are themselves a product of the pervasive dependency syndrome in postcolonial Africa. The utter reliance of Africa on foreign investment and imported goods and services is testament to this attitudinal fixation with its dependent development paradigm that has been wrongly elevated in intellectual discourses as the wisdom nuggets for Africa's economic transformation. Africa today is run as an outpost of the rest of the world by its own political and bureaucratic elite who believe, erroneously, that the best can only come from climes outside of Africa.

Related to the foregoing issue is the relegation of Research and Development (R\&D), innovation and inventions in Africa's public service establishments to the background. Professionals, especially scientists and technologists are not appropriately engaged in the fields of their competences. This situation has continued to create conditions for the formulation and implementation of policies that perpetuate the sustenance of the despicable extant economic relations between Africa and the rest of the world. Africa today is the consumer of finished technological products that are produced in other parts of the world, while the continent adds negligible value to the technological advancement of humanity. There is no hope of a change in sight in view 
of the paralyzing effects of the dependency policies of African Public Services on educational institutions in the continent. In contemporary times, the funding of the education sector and especially the meagre amounts allocated to higher education have affected the sciences more than the humanities because the teaching requirements of the former are incomparably higher than the latter. The libraries and laboratories of most African universities are deficient and inadequate in several respects. The resultant exodus of African intellectuals from Africa to other parts of the world consequent upon the degeneracy and progressive decay of African universities is a recurring phenomenon that has become known as 'brain drain.' Until there is a concerted effort by African governments to reverse this untoward trend, through improved funding of their educational institutions, placement of emphasis on Research and Development, and the promotion of innovations and inventions in Science and Technology, the industrial development of Africa will remain a mere mental construct and an illusionary expectation. The curricula of Africa's educational institutions need to be embedded with the useful skills of the $21^{\text {st }}$ century.

Another point that eludes the authors is the need to situate the dearth of industries in Africa within the context of the pervasive deterioration of African institutions of higher learning and the relegation of science and technologyrelated courses to the abyss of irrelevance in Africa's educational policies.
It is this misplacement of educational priority that is responsible for the rarity of indigenous industries in Africa. To attempt to fill the gap through the importation of foreign -run industries in Africa would only perpetuate Africa's dilemma of industrial poverty. Until Africans take responsibility for their industrial destiny, reliance on the goodwill of foreign investors for Africa's technological and industrial development will prolong and entrench the continent's dependency on the rest of the world.

Tim Harford's Fifty Inventions that shaped the Modern Economy documents the technological feats, discoveries and ideas that have enormously impacted the world beginning with the plow that kick-started civilization, and continuing with the gramophone, dynamo, razors and blades, the elevator, diesel engines, iPhones, chemical fertilizers, paper and paper money among other inventions. Harford classifies the different inventions into seven broad groups on the strength of their focus and levels of impact on humanity and the modern economy. These inventions he argues, have transformed the ways we work, play and live.

Such impactful inventions as infant formula, TV dinners, the pill, video games, barbed wires, google search, passports, robots, air-conditioning, department stores, market research, shipping container, clocks, barcode, cold chain, tradable debt and tally stick, radar, the bank, tax havens, leaded gasoline, antibiotics in farming, M-Pesa, property registers, index 
funds, s-bend, concrete, insurance, and the Billy bookcase are carefully appraised and their inventors commended. In addition, the author analyzes the historical evolution of great ideas such as those that birthed cuneiform, public-key cryptography double-entry bookkeeping, limited liability companies, management consulting, intellectual property, and the compiler, all of which have significantly influenced modern economic transactions globally.

Without any iota of doubt, there are more than fifty inventions in the $21^{\text {st }}$ century that have had profound impact on human existence and global society in general. The author has a visible bias toward purely positive inventions; those that are helpful in solving problems of social and economic interactions in the global community of humans, and that, by extension add value to the modern economy globally. However, the list of fifty inventions is neither exhaustive nor far-reaching enough. The list could be extended to include the breakthrough in reproductive health of humans and animals consequent upon the discovery of a near-perfect system of invitro-fertilization of female eggs by male semen in human and the artificial insemination of female animals which have both increased reproduction and by implication, the population of humans and animals thereby impacting the global economy. Another item that could be added, though on the flipside, is weaponry of different sizes, shapes and dimensions including guns, missiles, etc., which have made the pros- ecution of wars very costly, irrational and highly intolerable, thus deterring the prospects of war and consequently maintaining global peace.

Although no one can fault the importance of the fifty inventions presented in the book, they are mostly from outside of Africa with the notable exception of the M-Pesa technology which originated in Kenya (p.228) The book makes a passing reference to Africa in respect to the discovery of some samples of prehistoric writings in Iraq which were found by a German archeologist to have preceded those found in Egypt (p. 129). Thus, the bulk of the inventions under reference and the ideas that gave birth to them were from non-Africans but for the benefit of humanity. Were there no original thinkers and inventors in Africa? Why is Africa's past similar to its present-lacking human inventiveness? And why is Africa bereft of transformative ideas that could unleash their technological potentials for the advancement of humankind? In the light of the reality of the decadence of Africa's educational systems as articulated above, is there any hope that Africa will reclaim its industrial destiny? Africa's obvious lack of structural and ideological prerequisites for development may continue to militate against its plan to occupy a prominent space in the global map of industrialization.as a regional actor of worth. Harford's book was not written to address issues bordering on lack of inventiveness in any region of the world; it has nevertheless brought out the import of human inventiveness for the well- 
being of humanity and the greater good of the global economy.

Unlikely Partners by Julian Gewirtz tells the story of how China became the largest economy by purchasing power within the space of a little less than three decades from 1976 to 1993: a very short period to achieve such feat. The book identifies the significant roles played by Chinese leaders and foreign economic advisors in the period of change since 1976 when critical steps were taken to transform the thinking of the economic planners who have been working since that time to reform China's economy. The major thrust of Unlikely Partners contradicts popularly held views within and outside of China about the evident transformation of Communist China into a 'socialist market economy.' The author affirms his position by making copious references to original Chinese texts and statements made by prominent leaders of the Chinese Communist Party (CCP), to the effect that intellectual exchanges between China and the developed countries of the West, in particular, coupled with frequent visits by economic advisors from that part of the developed world had an enormous influence on the reform processes that successive governments in China, since the demise of Mao in 1976 introduced and implemented. Throughout the ten chapters of the book, the author chronicles the series of international engagements, conferences and other fora at which the foreign ideas espoused by international economists were well-received by Chinese audiences, a development that he describes as "a signature achievement that helped to define a golden age of openness and intellectual flexibility in China” (p. 272).

In the early parts of the book which dwelt extensively on the contestation of ideas between the rigid ideologues of socialism and communism and the reformers who were interested in injecting market-oriented policies into the management of industrial and commercial enterprises, the author notes the commitment of the postMao Chinese leaderships to the imperative of reforming China's economy for improved efficiency, wealth creation, development and poverty reduction. He expatiates that behind the receptiveness of Chinese leaderships to foreign ideas was the consensus among the reformers that China needed to depart from the tortuous and harrowing communist policies of the Mao years that failed China. It is interesting that, as the author remarks, the progressive engagement of the Chinese reformers and policy makers with foreign intellectuals and economists especially from the developed capitalist West resulted in making China's economy in all ramifications more like a Western market economy. This clearly depicts China's preference for development above ideological purity which the diehard ideologues of communism strenuously fought to retain but which was discountenanced by China's postMao leaderships as Gerwirtz points out.

However, despite the well-documented evidence of foreign input into China's transformation to the 
status of a global economic superpower, the book observes that the post-Mao Chinese leaderships are disinclined to admit that foreign influence played an important role in China's attainment of incredible development within the space of thirty years. It is duplicitous of the Chinese leadership to covertly admit the impactful influence of foreign ideas on China's development planning, while overtly and loudly attributing the country's economic miracle to their reformers' ingenuity.

No doubt, Julian Gewirtz has written an authoritative and expository masterpiece. His book offers a new perspective on the factors behind China's astounding economic transformation. The West and the rest of the developed world, to which the author ascribes the intellectual origin of China's reforms, are themselves humbled by the prosperous outcomes of their ideas in an enclave that not only forbids free market enterprise but is hostile to liberal democratic principles. This book gives the credit for what China has become today to the intellectual generosity of the developed West.

The only shortcoming of Unlikely Partners is conceptual. The author shows a strong bias against the ideological purification efforts of the current Chinese leadership which he considers a deviation from the openness promoted by Deng Xiaoping, when he says:

It will be deeply regrettable if the current leadership continues to sideline international engagements as one of the signature achievements of the reform era in china... And it will be worrying indeed if these leaders and their policy advisers turn inward and break with the tradition of beneficial openness, which Deng Xiaoping embraced throughout his tenure... (p. 275).

Related to that concern is the fact that the book could be met with incredulity for being a product of a Western scholar who could be subjective and perceived to be purely pursuing an agenda of exaggerating beyond reasonable proportions, the benefits derived by China from its innocuous intellectual exchanges with the West.

Regardless of these few critical remarks, the book conveys important lessons for Africa which has been and remains the theatre of so many failed ideas obtained from the developed world and economic advisors in international financial institutions. How did China utilize foreign ideas to become an economic behemoth while despite all of its series of engagements with Western ideas and other development paradigms, Africa continues to wallow in poverty and underdevelopment? The following quick points drawn from China's experience could be seen as lessons for Africa:

\section{i. Openness to beneficial develop-} ment ideas: Africa needs to reengage the world with a renewed perspective and be receptive to the positive influences of global financial institutions and economic ad- 
visors. China demonstrated humility to learn from abroad because its leaders realized that they had little knowledge with which to navigate their inchoate economy through the perilous tide of a highly competitive and overbearing global capitalist economy. As Julian Gewirtz observes, that process of learning was undertaken on a scale that has no match in human history. If China, an anti-imperialistic enclave, could engage Western intellectualism and obtain beneficial ideas to reposition its economy, Africa has to jettison its postcolonial hang-ups and the cynicism that has been hindering objectivity in development planning and the implementation of development policies.

ii. Thinking globally within the local context: Policy makers in Africa need to broaden and deepen their understanding of the international dynamics impinging on the economies of their different countries, and distill the diverse economic paradigms that they are exposed to in the crucibles of their disparate economies in relation to the global forces at work at any given point in time. Julian Gewirtz points out how Chinese intellectuals and decision-makers worked very hard to redefine the relationship between the State and the market in China in partnership with Western economists. China's leadership expended huge resources in procuring Western textbooks and other educational resources that were translated into Chinese for students in secondary and tertiary institutions in order to effect generational intellectual change that would be adaptable to the changes that the current Chinese leadership is emplacing. Africa needs to invest more in its knowledge economy in order to productively engage the world. The point needs to be emphasized that Africa's re-engagement with the world would be better served on a platform of partnership with friendly Western and Eastern economists and Africanists across the world similar to what the Chinese leadership did.

iii. No need to crave Foreign Direct Investment (FDI): The fallacy of modern economics literature in Africa is to blame the problems of poverty, diseases, hunger, and unemployment on the paucity or lack of foreign direct investment. The Chinese case has shown the dubiety of the apologists of FDI. The Chinese leaders developed their country's economy without soliciting for FDI. What they needed was knowledge capital from across the world, in particular from the West, which they got and utilized for the restructuring of the foundations of China's economy which had been ravaged by poverty during Mao's era. Africa should develop its workforce and confidently engage its human resources in the utilization of its endowments to turn its economy around as China has done. However, there is nothing wrong with FDI if it is regulated by the host countries to ensure that it is mutually beneficial to both Africa and the FDI investors.

In conclusion, it is very significant to affirm the relevance and intellectual utility of the three books reviewed 
here in understanding the dilemmas of Africa's development trajectory. The current global dynamics could present Africa as the winning ticket in the context of the unfolding competition for markets among the powerful global economic champions including the United States, Britain, the European Union countries and China. Of all these competitors for Africa's heart, China appears to be more appealing to African leaders because of its willingness to dispense huge low interest loans to Africa for infrastructural development. But will Africa utilize the loans prudently and judiciously as proposed? These loans could end up the way foreign aid from the West between the 1960s and 1980s was squandered if the requisite structures and superstructures as well as thoughtful ideas for their utilization are lacking. True, financial assistance could be useful but what would give Africa durable and enduring development is for African leaders to utilize Chinese pragmatic principles of getting the right development ideas from the world, and working assiduously to transform Africa with the energies of its people to meet its own developmental needs.

Acknowledgment: The author wishes to thank Professor Yemi Osinbajo, Vice President of the Federal Republic of Nigeria who gave each member of the country's Federal Executive Council (FEC) a set of these three books as a Christmas gift in December 2017. This author being then a member of the Secretariat and staff of the Cabinet Affairs Office (The Presidency) was privileged to receive a set of the three books. 